\title{
Pengaruh Model MEA dengan Pendekatan $R M E$ terhadap Kemampuan Pemecahan Masalah Pada Materi Perbandingan Kelas VII
}

\author{
Okta Asmara Yudha ${ }^{1}$, Rosmaiyadi ${ }^{2}$, Nurhayati ${ }^{3}$ \\ Pendidikan Matematika, STKIP Singkawang, Singkawang, Indonesia

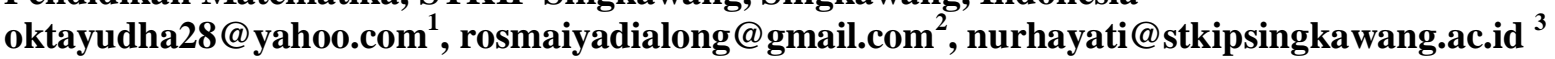

\begin{tabular}{lll}
\hline \hline Keywords : & ABSTRACT \\
Model Means-Ends Analysis & Penelitian ini bertujuan untuk mengidentifikasi pengaruh \\
(MEA) dengan Pendekatan & model MEA (Means-Ends Analysis) dengan Pendekatan \\
Realistic & Mathematic & RME (Realistic Mathematic Education $)$ terhadap \\
Education (RME) terhadap & kemampuan pemecahan masalah, perbedaan peningkatan \\
Kemampuan Pemecahan & kemampuan pemecahan masalah dan aktivitas belajar \\
Masalah, Aktivitas. & siswa pada materi perbandingan kelas VII MTs.N1 \\
& Singkawang 2018/2019. Penelitian ini menggunakan \\
& desain True Eksperimental. Populasi dalam penelitian ini \\
& adalah semua kelas VII MTs.N1 Singkawang yang terdiri \\
& dari lima kelas yang berjumlah 160 siswa. Sampel diambil \\
& dengan teknik nonprobability sampling. Adapun sampel \\
& yang dipilih terdiri dari dua kelas yaitu kelas VIIC sebagai \\
& kelas eksperimen dan kelas VIIE sebagai kelas kontrol. \\
& Hasil analisis menunjukkan: 1) Terdapat pengaruh \\
& penerapan model MEA dengan pendekatan RME terhadap \\
& kemampuan pemecahan masalah pada materi \\
& perbandingan kelas VII di MTs.N1 Singkawang \\
& 2018/2019; 2) Model MEA dengan pendekatan RME \\
& berpengaruh tinggi terhadap kemampuan pemecahan \\
& masalah; 3) Terdapat perbedaan peningkatan kemampuan \\
& pemecahan masalah matematis siswa pada materi \\
perbandingan antara yang mendapat pembelajaran \\
menggunakan model MEA dengan pendekatan RME dan \\
model pembelajaran langsung pada siswa kelas VII \\
MTs.N1 Singkawang 2018/2019; 4) Aktivitas siswa \\
tergolong tinggi saat proses pembelajaran pada tahun \\
2018/2019 menggunakan model MEA dengan pendekatan \\
RMEdi kelas VII MTs.N1 \\
\hline \hline
\end{tabular}

\section{INTRODUCTION}

Matematika merupakan salah satu cabang ilmu pengetahuan yang sangat bermanfaat bagi kehidupan manusia, sehingga menjadi salah satu mata pelajaran wajib yang ada dalam kurikulum pendidikan di Indonesia (Rohmah, 2018;187). Matematika juga merupakan ilmu yang mendasari perkembangan teknologi modern, mempunyai peranan penting dalam berbagai disiplin ilmu dan memajukan daya pikir manusia (Rosmaiyadi dkk, 2016:20). Matematika merupakan pengetahuan dasar yang berkaitan dengan fakta-fakta yang terorganisir, serta membahas ruang dan bentuk. Matematika sangat berhubungan dengan perkembangan ilmu pengetahuan lainnya. Hal itu dikarenakan hasil belajar 
matematika dapat membantu perkembangan dan penyelesaian masalah pada kehidupan secara langsung ataupun diterapkan kembali pada bidang pengetahuan lain. Oleh karena itu, matematika diajarkan mulai dari tingkat pendidikan rendah sampai pada tingkat tinggi agar dapat mengiringi dan membantu memecahkan masalah peserta didik ketika kehidupannya berkembang. Salah satu tujuan utama belajar matematika adalah meningkatkan kemampuan pemecahan masalah matematis siswa. Karena individu yang terampil memecahkan masalah akan lebih efektif ketika memenuhi kebutuhan hidupnya, menjadi pekerja yang lebih produktif, dan memahami isu-isu kompleks yang berkaitan dengan masyarakat global. Hal ini juga ditegaskan dalam Permendikbud Nomor 21 Tahun 2016 tentang Standar Isi yang menyatakan adanya kemampuan memecahkan masalah (Pasani, 2017;2-3).

Pemecahan masalah merupakan salah satu kemampuan matematik yang harus dikuasai siswa sekolah menengah. Pentingnya kemampuan pemecahan masalah tercermin dari pernyataan Prihatiningtyas \& Nurhayati (2017:13-14) Kemampuan pemecahan masalah merupakan satu diantara bagian yang penting di dalam kurikulum matematika, karena di dalam proses pembelajaran maupun penyelesaian siswa memungkinkan untuk dapat memperoleh pengetahuan serta menggunakan pengetahuan yang sudah dimiliki untuk digunakan dalam pemecahan masalah. Pendapat tersebut sejalan dengan pendapat Oftiana $(2017 ; 294)$ salah satu tujuan pembelajaran matematika menurut BNSP adalah agar peserta didik memiliki kemampuan pemecahan masalah yang meliputi kemampuan memahami masalah, merancang model matematika, menyelesaikan model dan menafsirkan solusi yang diperoleh. Tujuan tersebut menempatkan pemecahan masalah menjadi bagian dari kurikulum matematika yang penting.

Menurut Yuhani $(2018$,446) Kemampuan pemecahan masalah merupakan kemampuan menyelesaikan permasalahan non-rutin yang biasanya berhubungan dengan masalah dalam kehidupan nyata, dalam pembelajarannya pemecahan masalah lebih menekankan pada proses dan strategi. Kegiatan-kegiatan yang diklasifikasikan sebagai pemecahan masalah dalam matematika diantaranya menyelesaikan soal cerita dalam buku teks, menyelesaikan soal-soal tidak rutin atau memecahkan masalah teka-teki penerapan matematika pada masalah yang dihadapi dalam kehidupan nyata menciptakan dan menguji konjektur. Kemampuan pemecahan masalah matematik dapat diukur oleh suatu indikator, sebagai mana yang dikemukakan oleh Kusumawati $(2014 ; 262)$ sebagai berikut:

1. Memahami masalah yang diterima oleh siswa merupakan masalah yang belum diketahui cara menyelesaikannya.

2. Merencanakan penyelesaian masalah.

3. Melaksanakan penyelesaian masalah.

4. Memeriksa kembali penyelesaiannya.

Kemampuan pemecahan masalah dalam matematika itu adalah bagian yang sangat penting. Namun kenyataan di lapangan, kemampuan pemecahan masalah matematis peserta didik masih tergolong amat rendah, hal ini dapat dilihat dari hasil studi PISA (Program for International Student Assessment), yaitu menunjukkan peringkat Indonesia baru bisa menduduki 10 besar terbawah dari 65 negara didukung dengan hasil studi TIMSS (Trends in International Mathematics and Science Study) menunjukkan peserta didik Indonesia berada pada ranking amat rendah dalam kemampuan (1) memahami informasi yang komplek, (2) teori, analisis dan pemecahan masalah, (3) pemakaian alat, prosedur, dan pemecahan masalah, dan (4) melakukan investigasi. Berdasarkan uraian yang telah dipaparkan tersebut menunjukkan bahwa salah satu kemampuan yang masih tergolong rendah adalah kemampuan pemecahan masalah (Gusnidar dkk, 2017;63). Menurut Yahyawati (2013;4) Yang mempengaruhi rendahnya prestasi belajar siswa dikarenakan kurangnya penggunaan strategi pembelajaran yang sesuai dengan materi ajar. Selain itu kekurangan dari siswa yang tidak tertarik dengan pembelajaran matematika yaitu siswa merasa sulit untuk memahami soal sehingga siswa kesulitan dalam pemecahan masalah matematik yang dihadapi. Hal ini didukung oleh penelitian Kusumawati (2014;260-261) menemukan fakta, bahwa masih banyak siswa mengalami kesulitan dalam memecahkan masalah non rutin terutama masalah matematika yang berkaitan dengan kehidupan sehari-hari. Buyung, B., \& Nirawati, R (2018) memecahkan kesulitan matematika harus berkaitan dengan kehidupan sehari-hari. 
Salah satu materi pelajaran dalam matematika SMPN kelas VII yaitu Perbandingan, dimana dalam kehidupan sehari-hari banyak sekali masalah yang dapat diselesaikan dengan menggunakan konsep perbandingan,sehingga diperlukan kemampuan pemecahan masalah untuk menyelesaikan masalah tersebut. Selain kelemahan belajar matematika yang telah diuraikan diatas, terdapat juga kelemahan belajar matematika yang lebih terperinci pada materi perbandingan diantaranya adalah sebagai berikut: (1) sebagian besar siswa masih kurang mampu memahami soal cerita. (2) sebagian besar siswa kurang mampu membedakan soal perbandingan senilai dengan perbandingan berbalik nilai. Hal ini juga diperkuat dengan hasil prariset, penulis memberikan soal yang mengandung indikator pemecahan masalah kepada 34 siswa MTs.N1 Singkawang.

Dari hasil prariset tersebut dapat diketahui bahwa kemampuan pemecahan masalah matematis masih tergolong rendah. Rendahnya hasil siswa dalam menyelesaikan masalah, disebakan aktivitas siswa selama proses pembelajaran yang berlangsung masih rendah. Hal tersebut dilihat dari observasi yang dilakukan peneliti bahwa siswa kurang aktif dalam belajar,tidak mau bertanya maupun menjawab, kurang bersemangat dalam mengerjakan latihan atau soal yang diberikan, dan siswa cenderung kurang serius ketika pembelajaran berlangsung. Jadi dapat disimpulkan aktivitas siswa sangat mendukung terjadinya proses belajar mengajar agar berjalan sesuai tujuan. hal ini juga didukung oleh pendapat Sutrisno $(2012 ; 84)$ aktivitas atau kegiatan pembelajaran merupakan suatu rangkaian kegiatan dalam proses pembelajaran. Oleh Karena itu diperlukan suatu pembelajaran yang dapat membuat siswa senang untuk belajar matematika, dapat menghubungkan konsep pemikiran yang dimilikinya ke dalam dunia nyata agar dapat memotivasi siswa untuk menerapkan pengetahuannya ke dalam kehidupan mereka sehari-hari sehingga kemampuan pemecahan masalah matematika siswa meningkat. Salah satu pembelajaran yang sesuai untuk diterapkan adalah model pembelajaran Means-Ends Analysis (MEA) dengan pendekatan Realistic Mathematics Education (RME).

Pendekatan RME merupakan pendekatan dalam pembelajaran matematika yang memiliki karakteristik adanya penemuan-penemuan ide atau konsep matematika oleh siswa melalui dunia nyata atau masalah riil sebagai tolak ukur pembelajaran. Ini berarti bahwa dalam pembelajaran matematika, siswa diajak untuk mengaitkan konsep-konsep matematika dengan masalah kontekstual, sehingga konsep matematika yang bersifat abstrak bisa terealisasikan dipikiran siswa untuk menyelesaikan permasalahan yang berhubungan dengan matematika. Hal ini sejalan dengan pendapat Putri $(2012 ; 235)$ RME adalah salah satu pendekatan pembelajaran yang akan mengiring siswa memahami konsep matematika dengan mengkonstruksi sendiri melalui pengetahuan sebelumnya yang berhubungan dengan kehidupan sehari-harinya, dengan menemukan sendiri konsep tersebut, maka diharapkan belajar siswa menjadi bermakna. Hal tersebut didukung oleh penelitian yang dilakukan oleh Danoebroto $(2008$;84) yang menyimpulkan bahwa kemampuan siswa memecahkan masalah yang memperoleh pembelajaran matematika dengan pendekatan RME dan pelatihan metakognitif lebih unggul dibandingkan dengan pendekatan konvensional, serta siswa menyatakan senang pembelajaran dan kegiatan pemecahan masalah, memiliki keyakinan positif, menunjukkan antusiasme, keceriaan dan kreativitas yang tinggi dalam proses pembelajaran matematika.

Menurut Supendi dkk (2017;3) Model Means Ends Analysis adalah pembelajaran yang dikembangan dari metode pemecahan masalah maka siswa harus memiliki kemampuan pemecahan masalah matematis. Kemampuan pemecahan masalah matematis merupakan aspek yang penting dalam pembelajaran matematika. Pembelajaran dengan model Means Ends Analysis merupakan suatu metode pembelajaran yang dimana siswa dibentuk menjadi kelompok-kelompok kecil beranggotakan 4-6 siswa, kemudian dalam menganalisis permasalahan siswa harus memisahkan permasalahan yang diketrahui dan tujuan yang akan dicapai yang kemudian mengidentifikasi perbedaan serta memilih cara untuk mengurangi perbedaan-perbedaan tersebut. Dalam pembelajaran dengan model Means 
Ends Analysis ini siswa tidak hanya dinilai pada hasil pengerjaannya, namun juga dinilai pada proses pengerjaan. Proses pembelajaran seperti ini diharapkan dapat memberikan pengaruh positif terhadap kemampuan pemecahan masalah matematis siswa. Dari beberapa hasil penelitian yang menggunakan model Means Ends Analysis pada pembelajaran matematika yang hasilnya menunjukkan peningkatan kemampuan pemecahan masalah matematis siswa, yaitu penelitian Susanti $(2017 ; 10)$ terdapat pengaruh model MEANS ENDS ANALYSIS terhadap kemampuan pemecahan masalah matematika siswa Kelas VIII SMP Negeri 2 Lubuklinggau Tahun Pelajaran 2016/2017. Berdasarkan penjelasan di atas, peneliti tertarik untuk melakukan penelitian dengan judul "PENGARUH MODEL MEA DENGAN PENDEKATAN RME TERHADAP KEMAMPUAN PEMECAHAN MASALAH PADA MATERI PERBANDINGAN KELAS VII DI MTSN1 SINGKAWANG 2018/2019”

\section{METHOD}

Jenis penelitian adalah eksperimen dengan pendekatan kuantitatif. Penelitian ini menggunakan desain penelitian pretest-posttest control group design. Populasi dalam penelitian ini adalah seluruh siswa kelas VII MTs.N1 tahun ajaran 2018/2019 yang terdiri dari lima kelas yaitu kelas VIIA, VIIB, VIIC, VIID, dan VIIE. Teknik pengambilan sampel yang digunakan adalah teknik nonprobability sampling, Adapun sampel dalam penelitian ini adalah kelas VIIC dan VIIE, dengan kelas VIIC sebagai kelas eksperimen dan kelas VIIE sebagai kelas kontrol, terpilihnya kelas tersebut atas rekomendasi guru mata pelajaran matematika MTs.N1 Singkawang.

Instrumen pengumpulan data yang digunakan dalam penelitian ini adalah soal tes (Pre-test dan Posttest) yang berbentuk soal essay (uraian) dan lembar pengamatan aktivitas belajar siswa. Teknik analisis data penelitian ini adalah uji-t untuk mengetahui pengaruh model MEA dengan pendekatan $R M E$ terhadap kemampuan pemecahan masalah, efeect size untuk mengetahui seberapa besar pengaruh model $M E A$ dengan pendekatan $R M E$ terhadap kemampuan pemecahan masalah, dan uji Gain untuk mengetahui perbedaan peningkatan kemampuan pemecahan masalah matematis siswa pada materi Perbandingan antara yang mendapat pembelajaran menggunakan model MEA dengan pendekatan $R M E$ dan model pembelajaran langsung.

\section{RESULTS AND DISCUSSIONS}

1. Kemampuan Pemecahan Masalah

Hasil penelitian di MTs.N1 Singkawang, data kemampuan pemecahan masalah siswa diperoleh dari hasil pre-test dan post-test kemampuan pemecahan masalah. Data hasil pre-test diperoleh sebelum diberi perlakuan, sedangkan data hasil post-test diperoleh setelah diberi perlakuan yaitu pembelajaran menggunakan model $M E A$ dengan pendekatan $R M E$ pada materi perbandingan. Maka untuk mengetahui pengaruh model MEA dengan Pendekatan RME menggunakan rata-rata hasil post-test pada kelas eksperimen dan kelas kontrol. Adapun rekapitulasi nilai rata-rata post-test kelas eksperimen dan kelas kontrol ditinjau dari keseluruhan data disajikan pada Tabel 1 berikut:

Tabel 1. Rekapitulasi Nilai Rata-rata Post-Test Kelas Eksperimen dan Kelas Kontrol

\begin{tabular}{ccc} 
Keterangan & Kelas Eksperimen & Kelas Kontrol \\
\hline Rata - rata Post-test & 83,28 & 62,11 \\
\hline Standar Deviasi (SD) & 9,2 & 16,7
\end{tabular}

Kemudian dari data tersebut dilakukan uji normalitas data post-test kelas ekperimen dan kelas kontrol untuk mengetahui data tersebut berdistribusi normal dengan pengujian Apabila $x_{\text {hitung }}^{2}<x_{\text {tabel }}^{2}$ maka data berdistribusi normal dan apabila $x_{\text {hitung }}^{2}>x_{\text {tabel }}^{2}$ maka data tidak berdistribusi normal. Adapun pengujian normalitas data post-test kelas eksperimen dan kelas kontrol hasil nya data tersebut berdistribusi normal, sehingga dilakukan pengujian dengan menggunakan uji t untuk menguji apakah terdapat pengaruh pengaruh model $M E A$ dengan pendekatan $R M E$ terhadap kemampuan pemecahan masalah, dengan kaidah pengujian nya yaitu jika $t_{\text {hitung }} \leq t_{\text {tabel }}$ maka $\mathrm{H}_{\mathrm{o}}$ diterima dan $\mathrm{H}_{\mathrm{a}}$ ditolak, dan jika $t_{\text {hitung }}>t_{\text {tabel }}$ maka 
$\mathrm{H}_{\mathrm{o}}$ ditolak dan $\mathrm{H}_{\mathrm{a}}$ diterima. hasil nya adalah $6,8>2,03$ maka Ho ditolak dan Ha diterima. Dengan demikian dapat dikatakatan terdapat pengaruh model $M E A$ dengan pendekatan $R M E$ terhadap kemampuan pemecahan masalah. setelah itu dilakukan pengujian effect Size dengan hasil 1,3 yang berarti model MEA dengan pendekatan $R M E$ berpengaruh tinggi terhadap kemampuan pemecahan masalah.

Penilaian Kemampuan pemecahan masalah matematis siswa di nilai dari skor rata-rata kemampuan pemecahan masalah matematis siswa. Adapun indikator dalam penelitian ini adalah a) Memahami masalah dengan skor 3 b) Menyusun rencana penyelesaian masalah dengan skor 4 c) Melaksanakan rencana penyelesaian masalah dengan skor 4 d) Memeriksa kembali penyelesaian dengan skor 4, yang terdiri dari 2 buah soal essay dengan total skor 28. Maka berdasarkan Hasil pre-test dan post-test kemampuan pemecahan masalah kelas eksperimen dan kontrol, rata-rata skor untuk setiap indikator kemampuan pemecahan masalah matematis siswa dapat dilihat pada tabel 2 sebagai berikut.

Tabel 2. Rata-rata Skor Tiap Indikator Kemampuan Pemecahan Masalah Siswa Kelas Eksperimen dan Kontrol

\begin{tabular}{ccccccc}
\hline $\begin{array}{c}\text { Indikator } \\
\text { Kemampuan } \\
\text { Pemecahan } \\
\text { Masalah }\end{array}$ & \multicolumn{3}{c}{ Rata-rata } & \multicolumn{2}{c}{ Selisih Rata-rata } \\
\cline { 2 - 7 } & $\begin{array}{c}\text { Kelas } \\
\text { Eksperimen }\end{array}$ & \multicolumn{2}{c}{ Kelas Kontrol } & Pre-test & Post-test \\
\cline { 2 - 7 } & $\begin{array}{c}\text { Pre- } \\
\text { test }\end{array}$ & $\begin{array}{c}\text { Post- } \\
\text { test }\end{array}$ & $\begin{array}{c}\text { Pre- } \\
\text { test }\end{array}$ & $\begin{array}{c}\text { Post- } \\
\text { test }\end{array}$ & $\begin{array}{c}\text { Kelas } \\
\text { Eksperimen } \\
\text { dan Kontrol }\end{array}$ & $\begin{array}{c}\text { Kelas } \\
\text { Eksperimen } \\
\text { dan Kontrol }\end{array}$ \\
\hline $\begin{array}{c}\text { Memahami } \\
\text { masalah }\end{array}$ & 1,54 & 2,36 & 1,54 & 1,99 & 0 & 0,37 \\
\hline $\begin{array}{c}\text { Menyusun } \\
\text { rencana } \\
\text { penyelesaian } \\
\text { masalah }\end{array}$ & 1,73 & 3,43 & 1,31 & 2,67 & 0,42 & 0,76 \\
\hline $\begin{array}{c}\text { Melaksanakan } \\
\text { rencana } \\
\text { penyelesaian } \\
\text { masalah }\end{array}$ & 1,34 & 3,5 & 1,07 & 2,52 & 0,27 & 0,98 \\
\hline $\begin{array}{c}\text { Memeriksa } \\
\text { kembali } \\
\text { penyelesaian }\end{array}$ & 1,08 & 2,39 & 0,92 & 1,68 & 0,16 & 0,71 \\
\hline
\end{tabular}

Persentase untuk setiap indikator kemampuan pemecahan masalah matematis siswa dari kelas eksperimen dan kontrol disajikan dalam diagram Gambar 1 sebagai berikut. 


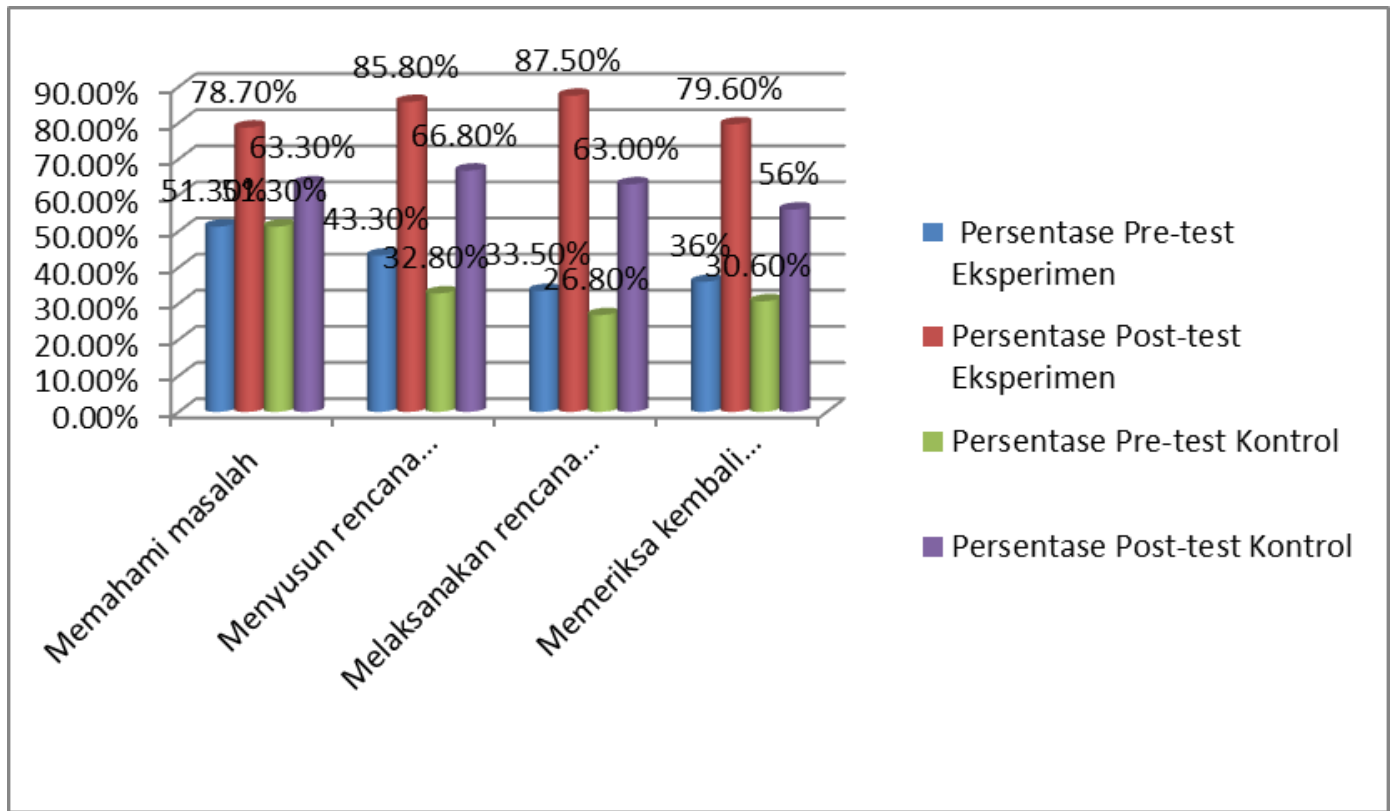

\section{Gambar 1. Diagram Persentase Skor Siswa Tiap Indikator Kemampuan Pemecahan Masalah}

Berdasarkan Gambar 3 di atas, untuk semua indikator kemampuan pemecahan masalah memiliki perbedaan yang sangat signifikan antara kelas eksperimen dan kelas kontrol. Terlihat pada semua indikator kemampuan pemecahan masalah kelas eksperimen lebih tinggi dari pada kelas kontrol. Hal ini berarti bahwa terdapat peningkatan kemampuan pemecahan masalah matematis siswa kelas eksperimen setelah diterapkannya model $M E A$ dengan Pendekatan $R M E$. Maka selanjutnya akan dilakukan uji N-gain antara kelas eksperimen dengan kelas kontrol dan hasilnya akan di uji normalitasnya. Adapaun hasil yang diperoleh adalah sebagai berikut.

Tabel 3. Peningkatan Rata-rata Skor Tiap Indikator Kemampuan Pemecahan Masalah

\begin{tabular}{ccc}
\hline & Kelas Eksperimen & Kelas Kontrol \\
\hline $\begin{array}{c}\text { N-Gain Total } \\
\text { Keseluruhan } \\
\text { Indikator }\end{array}$ & 0,72 & 0,55 \\
\hline Kriteria & Tinggi & Sedang \\
\hline
\end{tabular}

Dari tabel 3 di atas, disimpulkan bahwa peningkatan kemampuan pemecahan masalah pada siswa adalah 0,72 di kelas eksperimen dengan kriteria tinggi dan 0,55 dikelas kontrol dengan kriteria sedang. Langkah selanjutnya dilakukan uji normalitas dengan hasil salah satu data berdistribusi tidak normal, sehingga dilakukan pengujian dengan menggunakan uji mann whitney dengan hasil Karena $\mathrm{Z}_{\text {hitung }} \geq \mathrm{Z}_{\text {tabel }}(6,9<1,96)$ maka $\mathrm{H}_{0}$ ditolak dan $\mathrm{H}_{\mathrm{a}}$ diterima. Artinya terdapat perbedaan peningkatan kemampuan pemecahan masalah matematis siswa pada materi Perbandingan antara yang mendapat pembelajaran menggunakan model $M E A$ dengan pendekatan $R M E$ dan model pembelajaran langsung.

2. Hasil Aktivitas Belajar Siswa

Dari hasil pengamatan dapat dinyatakan bahwa siswa aktif dalam mengikuti pembelajaran dengan menggunakan model MEA dengan Pendekatan RME. Hal ini dapat dilihat dari lembar pengamatan aktivitas belajar siswa pada pertemuan I dan pertemuan II yang diamati mulai dari proses pembelajaran sampai akhir pembelajaran. Adapun rekapitulasi hasil rata-rata pengamatan aktivita siswa pada pertemuan I dan II dapat dilihat pada tabel 19 sebagai berikut

Tabel 4. Rekapitulasi Hasil Pengamatan Aktivitas Belajar Siswa

Kategori Rata-rata Persentase Rata-rata Persentase




\begin{tabular}{ccc}
\hline Aktivitas Belajar & $\begin{array}{c}\text { Kategori Pada Pertemuan } \\
\mathbf{1}\end{array}$ & $\begin{array}{c}\text { Kategori Pada Pertemuan } \\
\mathbf{2}\end{array}$ \\
\cline { 2 - 3 } & Kelas Eksperimen & Kelas Eksperimen \\
\hline Oral Activities & $67,11 \%$ & $70,89 \%$ \\
\hline $\begin{array}{c}\text { Listening } \\
\text { Activities }\end{array}$ & $76,22 \%$ & $78,89 \%$ \\
\hline Mental Activities & $70,19 \%$ & $72,04 \%$ \\
\hline $\begin{array}{c}\text { Writting Activities } \\
\text { Rata-Rata } \\
\text { Persentase } \\
\text { Keseluruhan } \\
\text { Kategori }\end{array}$ & $71,78 \%$ & $74,22 \%$ \\
\hline
\end{tabular}

Dari tabel 4 di atas, dapat diketahui bahwa rata-rata persentase aktivitas belajar siswa pada pertemuan I mencapai 71,3\% dengan kriteria tinggi dan Pertemuan II meningkat menjadi $74 \%$. Dengan demikian, aktivitas siswa tinggi saat proses pembelajaran menggunakan model $M E A$ dengan pendekatan $R M E$.

\section{CONCLUSION AND SUGGESTION}

Berdasarkan hasil penelitian yang telah dilakukan peneliti, dapat disimpulkan bahwa model $M E A$ dengan pendekatan $R M E$ berhasil diterapkan dengan hasil yaitu model $M E A$ dengan pendekatan $R M E$ memberikan pengaruh yang tinggi terhadap kemampuan pemecahan masalah pada materi perbandingan kelas VII di MTs.N1 Singkawang 2018/2019. sesuai dengan sub-sub rumusan masalah penelitian, secara khusus dapat disimpulkan hal-hal sebagai berikut: 1) Terdapat pengaruh penerapan model $M E A$ dengan pendekatan $R M E$ terhadap kemampuan pemecahan masalah pada materi Perbandingan kelas VII di MTs.N1 Singkawang 2018/2019. 2) Model $M E A$ dengan pendekatan $R M E$ berpengaruh tinggi terhadap kemampuan pemecahan masalah. 3) Terdapat perbedaan peningkatan kemampuan pemecahan masalah matematis siswa pada materi Perbandingan antara yang mendapat pembelajaran menggunakan model $M E A$ dengan pendekatan $R M E$ dan model pembelajaran langsung pada siswa kelas VII MTs.N1 Singkawang 2018/2019. 4) Aktivitas siswa tergolong tinggi saat proses pembelajaran pada tahun 2018/2019 menggunakan model MEA dengan pendekatan $R M E$ dikelas VII MTs.N1

Berdasarkan hasil penelitian, pembahasan dan kesimpulan yang telah didapat, terdapat beberapa saran guna penyempurnaan penelitian sejenis berikutnya. Adapun saran-saran sebagai berikut.

1.kepada peneliti atau pengajar yang ingin menerapkan model $M E A$ dengan pendekatan $R M E$ sebagai salah satu alternatif pengajaran hendaknya memperhatikan kecocokan dan kelayakan materi yang diajarkan

2. Bagi sekolah sebagai masukan untuk menentukan haluan kebijakan dalam membantu meningkatkan pemecahan masalah dan mengurangi kesulitan-kesulitan pembelajaran yang ada

3. Bagi siswa melalui model $M E A$ dengan Pendekatan $R M E$ diharapkan dapat meningkatkan kemampuan pemecahan masalah matematis siswa serta meningkatkan aktivitas siswa khususnya materi Perbandingan

\section{REFERENCES}

Buyung, B., \& Nirawati, R. (2018). Pengaruh Karakter Kerja Keras Terhadap Kemampuan Literasi Matematis Siswa Melalui Model Discovery Learning. JPMI (Jurnal Pendidikan Matematika Indonesia), 3(1), 21-25.

Danoebroto, S. W. (2008). Improving Problem Solving Skill Using The PMRI and Metacognitive Training. Jurnal Penelitian dan Evaluasi Pendidikan, Nomor, 1. 
Gusnidar, G., Netriwati, N., \& Putra, F. G. (2018). Implementasi Strategi Pembelajaran Konflik Kognitif Berbantuan Software Wingeom Dalam Meningkatkan Kemampuan Pemecahan Masalah Matematis. Jurnal Edukasi Matematika Dan Sains, 5(2), 62-69.

Huda, Miftahul.(2014). Model-model Pengajaran Dan Pembelajaran.Yogyakarta: Pustaka Pelajar

Oftiana, S.,\& Saefudin, A.A. (2017). PENGARUH PENDEKATAN PEMBELAJARAN MATEMATIKA REALISTIK INDONESIA (PMRI) TERHADAP KEMAMPUAN PEMECAHAN MASALAH MATEMATIKA SISWA KELAS VII SMP NEGERI 2 SRANDAKAN. MaPan: Jurnal Matematika dan Pembelajaran,5(2), 293-301.

Pasani, C. F., \& Al Fajar, Y. R. (2017). Meningkatkan Kemampuan Pemecahan Masalah Matematis Siswa Kelas VIII-F SMPN 14 Banjarmasin Melalui Model Pembelajaran Means End Analysis (MEA). EDU-MAT, 4(2).

Prihatiningtyas, N. C., \& Nurhayati, N. (2017). PENERAPAN MODEL PEMBELAJARAN MEANSENDS ANALYSIS UNTUK MENINGKATKAN KEMAMPUAN PEMECAHAN MASALAH MATEMATIS SISWA. JPMI (Jurnal Pendidikan Matematika Indonesia), 2(1), 13-18.

Putria, A., Akhyar, M., \& Agung, L. (2017, March). Urgensi Buku Digital Berbasis Realistic Mathematics Education dalam Pembelajaran Matematika. In Prosiding Seminar Nasional Teknologi Pendidikan.

Putri, R. I. I. (2012). Pembelajaran materi bangun datar melalui cerita menggunakan pendekatan pendidikan matematika realistik indonesia (PMRI) di sekolah dasar. Jurnal Pendidikan dan Pembelajaran (JPP), 18(2), 235-240.

Rohmah, Z. F., Triyanto, T., \& Fitriana, L. (2018). EKSPERIMENTASI MODEL PEMBELAJARAN TWO STAY TWO STRAY DENGAN PENDEKATAN SAVI PADA MATERI TEOREMA PYTHAGORAS DITINJAU DARI AKTIVITAS BELAJAR KELAS VIII SMP NEGERI 2 JATEN TAHUN PELAJARAN 2017/2018. Jurnal Pendidikan Matematika dan Matematika SOLUSI, 2(3), 187-193.

Sari, A. N., Wahyuni, R., \& Rosmaiyadi, R. (2016). Penerapan Pendekatan Open-Ended untuk Meningkatkan Kemampuan Berpikir Kritis Siswa Pada Materi Aljabar Kelas VIII SMP Negeri 10 Pemangkat. JPMI (Jurnal Pendidikan Matematika Indonesia), 1(1), 20-24.

Shoimin Aris. (2014).68 MODEL PEMBELAJARAN INOVATIV DALAM KURIKULUM 2013. Yogyakarta: AR-RUZZ MEDIA

Sulistyarini, D. A. (2013). Penerapan Pembelajaran Rme Dengan Strategi Pembelajaran Means Ends Analysis Untuk Meningkatkan Kemampuan Berpikir Kritis Pada Materi Lingkaran (PTK Pada Siswa Kelas VIII SMP N 1 Kartasura Tahun 2012/2013) (Doctoral dissertation, Universitas Muhammadiyah Surakarta).

Supendi, A., Jamiah, Y., \& Ahmad, D. (2017). Model Means Ends Analysis dan Direct Intruction terhadap Kemampuan Pemecahan Masalah Matematis Siswa. Jurnal Pendidikan dan Pembelajaran, 6(2).

Susanti, E.(2017). PENGARUH MODEL PEMBELAJARAN MEANS-ENDS ANALYSIS TERHADAP KEMAMPUAN PEMECAHAN MASALAH MATEMATIKA SISWA KELAS VIII SMP NEGERI 2 LUBUKLINGGAU TAHUN PELAJARAN 2016/2017. 
Sutrisno (2012). Kreatif Mengembangkan Aktivitas Pembelajaran Berbasis TIK. Jakarta: Referensi

Yahyawati, D. (2013). Penerapan Model Pembelajaran Means Ends Analysis Untuk Meningkatkan Kemampuan Siswa Dalam Pemecahan Masalah Matematika (PTK Pembelajaran Matematika pada Siswa Kelas VII SMP Negeri 1 Nogosari Semester Genap Tahun Ajaran 2012/2013) (Doctoral dissertation, Universitas Muhammadiyah Surakarta).

Yuhani, A., Zanthy,L.S.,\& Hendriana, H. (2018). PENGARUH PEMBELAJARAN BERBASIS MASALAH TERHADAP KEMAMPUAN PEMECAHAN MASALAH MATEMATIS SISWA SMP. JPMI (Jurnal Pembelajaran Matematika Inovatif), 1(3), 445-452. 